\title{
Effect of training on knowledge, attitude and practice of safety measures among battery chargers in Ilorin metropolis
}

\author{
*Uthman M.M.B. ${ }^{1,2}$, Salaudeen A.G. ${ }^{1,2}$, Rotimi B.F. ${ }^{1,2}$, Uthman A.O. ${ }^{3}$, Oloyede H.K. ${ }^{2}$, \\ Omojasola T.P. ${ }^{2}$, Musa O.I. ${ }^{1,2}$
}

\begin{abstract}
Objective: Good knowledge of safety measures against hazards of lead-acid battery work is important in the control of the work-related health problems. The study assessed the effects of training on knowledge, attitude and practice of safety measures among battery chargers in Ilorin, Nigeria.
\end{abstract}

Methods: The study was a quasi-experimental (non-randomized) study with pretest and post-test design. A total of 107 battery chargers were recruited each for intervention and control group. The study group was offered training on occupational safety measures while the control group did not have training at this stage. Post intervention data was collected 12 weeks after the pre-intervention. Multistage sampling technique was used to select 214 registered battery chargers working in Ilorin in to the study. Data obtained through interviewer-administered questionnaires were analysed using SPSS version 16 software.

Results: Less than one-fifth (15.9\%) of the study group had good knowledge of hazards relating to battery which increased significantly to more than three-quarters $(76.2 \%)$ post-intervention. The majority $(85.0 \%)$ of the study group and $(86.0 \%)$ of the control group had positive attitude towards safety measures pre-intervention. There was no significant improvement in attitude post intervention. The safety practice of less than one-tenth $(6.5 \%)$ of the study group was rated good pre-intervention which increased significantly to almost one-fifth (17.8\%) post-intervention. There was no significant improvement in the Kwowledge, attidude or practice of safety measures among the control group post intervention.

Conclusion: Association of the battery chargers should organize in conjunction with the health institutions training of their members on hazards prevention and safety practices.

Key words: Training, battery, safety measures, workers, Ilorin.

\footnotetext{
*Correspondence author

Uthman M.M.B.

http://orcid.org/0000-0002-3012-195X

Email:uthmanmb@yahoo.com
}

\footnotetext{
${ }^{1}$ Department of Epidemiology and Community Health, Faculty of Clinical Sciences, College of Health Sciences, University of Ilorin, Ilorin, Nigeria

${ }^{2}$ Department of Epidemiology and Community Health, University of Ilorin Teaching Hospital, Ilorin, Nigeria

${ }^{3}$ Warwick-Centre for Applied Health Research and Delivery (WCAHRD), Warwick Medical School, University of Warwick, Coventry, UK
}

Research Journal of Health Sciences subscribed to terms and conditions of Open Access publication. Articles are distributed under the terms of Creative Commons Licence (CC BY-NC-ND 4.0). (http://creativecommons.org/licences/by-nc-nd/4.0).

http://dx.doi.org/10.4314/rejhs.v7i2.7 


\title{
Effet de la formation sur la pratique des mesures de sécurité parmi les chargeurs de batterie dans la métropole d'Ilorin
}

\author{
*Uthman M.M.B. ${ }^{1,2}$, Salaudeen A.G. ${ }^{1,2}$, Rotimi B.F. ${ }^{1,2}$, Uthman A.O. ${ }^{3}$, Oloyede H.K. ${ }^{2}$, \\ Omojasola T.P. ${ }^{2}$, Musa O.I. ${ }^{1,2}$
}

\begin{abstract}
Resume
Objectif: Une bonne connaissance des mesures de sécurité contre les risques liés au travail dans des batteries plomb-acide est importante pour la maîtrise des problèmes de santé liés au travail. L'étude a évalué les effets de la formation sur les connaissances, l'attitude et la pratique des mesures de sécurité parmi les chargeurs de batterie à Ilorin, au Nigéria.
\end{abstract}

Méthodes: L'étude était une étude quasi expérimentale (non randomisée) avec une conception pré-test et post-test. Au total, 107 chargeurs de batterie ont été recrutés pour les groupes d'intervention et de contrôle. Une formation sur les mesures de sécurité au travail a été proposée au groupe d'étude alors que le groupe de contrôle n'avait pas de formation à ce stade. Les données post-intervention ont été collectées 12 semaines après l'intervention. Une technique d'échantillonnage en plusieurs étapes a été utilisée pour sélectionner 214 chargeurs de batterie enregistrés travaillant à Ilorin dans l'étude. Les données obtenues au moyen de questionnaires administrés par un intervieweur ont été analysées à l'aide du logiciel SPSS version 16.

Résultats: Moins du cinquième (15,9\%) des membres du groupe d'étude avaient une bonne connaissance des risques liés aux piles, qui avaient augmenté de manière significative pour atteindre plus des trois quarts $(76,2 \%)$ après l'intervention. La majorité $(85,0 \%)$ du groupe d'étude et $(86,0 \%)$ du groupe témoin avaient une attitude positive à l'égard des mesures de sécurité avant l'intervention. Il n'y a pas eu d'amélioration significative de l'attitude après l'intervention. Les pratiques de sécurité de moins d'un dixième $(6,5 \%)$ du groupe d'étude ont été jugées bonnes avant l'intervention, ce qui a augmenté de manière significative jusqu'à presque un cinquième $(17,8 \%)$ après l'intervention. Il n'ya pas eu d'amélioration significative du Kwowledge, de l'attitude ou de la pratique des mesures de sécurité dans le groupe témoin après l'intervention.

Conclusion: L'association des chargeurs de batterie devrait organiser conjointement avec les institutions de santé la formation de leurs membres à la prévention des risques et aux pratiques de sécurité.

Mots clés: formation, batterie, mesures de sécurité, travailleurs, Ilorin.

\footnotetext{
*Auteur principal

Uthman M.M.B.

http://orcid.org/0000-0002-3012-195X

Email: uthmanmb@yahoo.com

${ }^{1}$ Department of Epidemiology and Community Health, Faculty of Clinical Sciences, College of Health Sciences, University of Ilorin, Ilorin, Nigeria

${ }^{2}$ Department of Epidemiology and Community Health, University of Ilorin Teaching Hospital, Ilorin, Nigeria

${ }^{3}$ Warwick-Centre for Applied Health Research and Delivery (WCAHRD), Warwick Medical School, University of Warwick, Coventry, UK
} 


\section{INTRODUCTION}

Lead acid battery is a power supply system, which is critical to transportation, communication, electric utilities and functions as an emergency backup system (1). There is great utility of battery in day-to-day life and it has mainly lead (70\%), acid (20\%) and plastic case $(10 \%)$. Lead $(\mathrm{Pb})$ is a highly toxic metal with no known physiological benefits to man (2).

Lead-acid battery industry is associated with varieties of occupationally related health problems (3). These health problems arise because of contact with dangerous components and procedures involved in the work. Employees in lead smelting, refining and manufacturing industries develop highest and sustained jobrelated exposures to lead (4). The main exposure pathways for workers are inhalation and accidental ingestion of lead-bearing dust particles and fumes. Also, work-related exposures are very important source of secondary exposure for workers' families through leadcontaminated dust on their skin, clothes and, or shoes (5).

Awareness and good knowledge of safety measures against hazards of lead-acid battery work are important in the control of the work-related health problems. It is expected that workers who are aware of the hazards of the work and safety measures are more likely to shield themselves from the dangers of the work. The workers involved in the charging and repair of the lead-acid batteries are not aware of the hazards relating to their work (6).

The study of small scale industrial workers in Saudi Arabia reported that $9 \%$ of workers had no knowledge of preventive measures (7). These workers were not equipped with information on how to protect themselves from hazards associated with their work. Similarly in China, Wei reported that less than a third $(32 \%)$ of the small scale industry workers in Shangai had adequate knowledge of hazards of their work (8). Lesser proportion $(11 \%)$ of the workers were aware of the harm the hazards of their work can cause their health. Similarly in Italy, fewer $(18 \%)$ of small-scale industry workers were aware of the hazards of their work such as dust, fume, vapour and chemicals (9). These workers did not protect themselves against these hazards even when protective devices such as facemasks are made available to them free of charge.

In a study of battery workers in Philippine, personnel observed working in the battery reconditioning shops were not wearing any protective clothing, gloves or safety goggles (10). Some of the personnel working in the shops wore only shorts, no shirts or shoes, and others who were wearing tee shirts wore only sandals on their feet.

High proportion of lead exposed workers in Japan had good practice of safety measures (11). Majority of the workers $(92 \%)$ and (84\%) always use face mask and glove respectively at work (11). Almost all the workers (93\%) always wash hand before meal at work. More than half of the workers (52\%) always wash their face before meal at work (11). However, nearly half (49\%) of the workers smoke cigarette and all reported smoking cigarette at work (11).

Few $(19.7 \%)$ of the small scale industry workers in China had personal protective devices in their workplace (8). Furthermore, very few $(4.6 \%)$ of the workers had knowledge of health regulations on their work. The study of small scale industry workers in Saudi Arabia revealed that $60 \%$ of the workers do not use personal protective devices at work (7).

A report of occupational health education as training conducted for all workers and managers on methods of reducing the risk of lead poisoning of workers at an assembly section in a battery manufacturing plant in Bangkok, Thailand in 2002 revealed a significant improvement in the knowledge of safety measures against toxicity of lead battery (12). There was improvement in the workers' attitude towards personal hygiene. Following the training, the workers started complying with the instruction of "no smoking" in the workplace (12). Furthermore, the workers started washing their hands with water and detergent before drinking or eating at work. Some workers started taking a bath at work after the day's work before going home (12). The workers especially took off working clothes at the office outside the workplace and washed them every day (12). The study assessed the effects of training on knowledge, attitude and practice of safety measures among battery chargers in Ilorin, Nigeria.

\section{MATERIALS AND METHODS Description of Study Area}

The study was carried out in Ilorin the capital of Kwara State, North-central Nigeria. The Association of Lead Acid Battery Chargers in Ilorin has 651 registered members. Membership of this association is compulsory for all the battery chargers practicing in Ilorin. Ilorin West Local Government has 4 zones with 213 
members, Ilorin East Local Government has 4 zones with 253 members while, Ilorin South Local Government has 4 zones with 185 members.

\section{Study Design}

The study was a quasi-experimental (non-randomized) study with pretest and posttest design, which was conducted in three stages as follows:

\section{Pre-intervention phase}

A cross-sectional descriptive study with the use of semi-structured, interviewer administered questionnaire was used to generate baseline information on socio-demographic characteristics, occupational history, knowledge, attitude and practices of safety measures among the battery chargers in both the study and control groups.

\section{Intervention phase}

In the intervention stage, the study group was offered a day training on occupational safety measures as applied to the prevention of lead poisoning while the control group did not have training at this stage. The training conducted free of charge to the participants. Information, Media, Education and communication (IMEC) materials were used as interventional strategies and this was packaged in form of didactic lectures using audiovisual, role-plays and practical demonstrations.

The content of the training included preventive measures on the hazards associated with battery repair and lead, and demonstration of safety practices. The training materials were sourced from Washington State Department of Labour and Industries's Safety, Health Assessment and Research for Prevention (SHARP) Programme on lead (13) and United Nations Conference on Trade and Development (UNCTAD) documents (10). Also, WHO Training Package for the Health Care Providers on lead was also utilized for the training (14).

The sessions were conducted in the local language and made as participatory as possible. The trainings were conducted in each zone with a maximum of 33 participants at a session. Each participant was exposed to a session of the training. In all, a total of four sessions of training were conducted over a period of two weeks. The venues of the training were the meeting hall of the Battery Chargers' Association in each zone.

To allow uniformity, the same resource persons and materials were used consecutively at zonal trainings.

\section{Post-intervention}

The post intervention phase was conducted 12 weeks after intervention to allow any sustained behavioural change in the intervention group. The cross sectional study similar to the pre-interventional study was repeated with the use of the same, interviewer administered, semi-structured questionnaire. The control group was offered training after post intervention data has been collected as community service.

\section{Study Population}

The study population consisted of 107 lead acid battery chargers from Ilorin South Local Government Area while the control group consisted of 107 lead acid battery chargers from Ilorin East Local Government of Kwara State. The register of their association was the basis for the selection into the study.

Inclusion criteria: Lead acid battery chargers registered with the association of battery chargers and practicing within Ilorin South and East Local Government Area were included in this study.

Exclusion criteria: Apprentice and unregistered battery chargers were excluded from this study.

\section{Sample Size Determination}

The minimum sample size for the study for each group was calculated using the formula for comparison of two proportions (comparing the intervention group with the control group)(15).

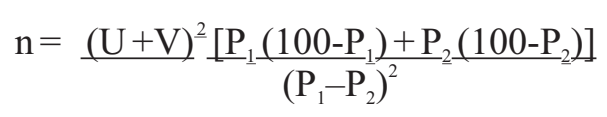

$\mathrm{n}=$ minimum sample size

$\mathrm{U}=$ Standard Normal Deviate (SND) corresponding to the power of $80 \%=0.84$

$\mathrm{V}=$ Standard Normal Deviate corresponding to the confidence level of $95 \%$ for a tailed test $=1.96$ $\mathrm{P}_{1}=10 \%$ (proportion of the battery chargers that uses safety glove as an item of practice of safety measures) (16).

$\mathrm{P}_{2}=25 \%$ (a difference of $15 \%$ improvement in the use safety glove is anticipated to be achieved by the intervention).

$$
\mathrm{n}=\left(\underline{0.84+1.96)^{2}} \frac{[(10 \times 90)+(25 \times 75)]}{(10-15)^{2}}=96.7\right.
$$


To compensate for attrition, the sample size was calculated as follows using the formula;(17).

$\mathrm{n}=$ Calculated Sample Size of battery chargers ns $=$ Sample Size to compensate for attrition. $\mathrm{ns}=\mathrm{n} \quad$ (anticipating 10\% attrition) $\overline{0.90}$ $\mathrm{ns}=107$

Therefore a total of 107 battery chargers were recruited each for intervention and control group making a total of 214 respondents each in pre intervention phase and post intervention phase of the study.

\section{Sampling Technique}

A multi-stage sampling technique was used to recruit battery chargers into study and control groups and carried out in four stages thus: Using simple random sampling method by balloting Ilorin South Local Government and Ilorin East Local Government were selected out of the three LGAs in Ilorin. Simple random sampling method using ballot technique was used to assign Ilorin South Local Government as the study group and Ilorin East Local Government as the control group. Three zones were selected by balloting out of four zones from Ilorin South and East Local Government Areas respectively.

Systematic sampling method was used to recruit respondents from the zones utilizing the zonal nominal roll of registered battery chargers as sampling frame. The allocated proportion of the total sample size to obtain Sampling Interval (S) divided the total number of the registered members of each zone. The first participants were taken randomly thereafter; every second member $(\mathrm{S}=2)$ was selected using the zonal register until required numbers of participants were recruited for each zone in both groups. In both groups, any eligible members who was either absent or declined participation were replaced by the next consenting name on the sampling frame.

\section{Research Instrument and Data Collection}

A semi-structured interviewer administered questionnaire with majority of the items close ended while few items were open ended on measures of hazard prevention and measures to prevent secondary exposure to hazards of lead acid battery.

\section{Knowledge of safety measures and hazards of lead battery repair work}

There were 15 questions in all. Each correct response was scored 1 mark while the incorrect response was scored zero. The total obtainable score for the safety measures knowledge questions was 15 . The score 0 to 8 was graded as poor knowledge of safety measure while score 9 to 15 was graded as good knowledge of safety measure.

There were 15 questions in all. Each correct response was scored 1 mark while the incorrect response was scored zero. The total obtainable score for the hazards' knowledge questions was 15 . The score 0 to 8 was graded as poor knowledge of hazards of lead battery repair work while score 9 to 15 was graded as good knowledge of hazards of lead battery repair work.

\section{Attitude towards the practice of occupational safety measures}

There were 2 questions in all. The psychometric scale had five options from strongly disagree, disagree, undecided, agree and strongly agree with $1,2,3,4$, and 5 points respectively. Strongly disagree to undecided indicate negative attitude while agree to strongly agree indicate positive attitude. The maximum obtainable point for the attitude questions was 10 . The score of 2 to 5 was graded as negative attitude toward practice of occupational safety measures while score of 6 to 10 was graded as positive attitude toward practice of occupational safety measures.

\section{Self reported practice of occupational safety measures}

There were 14 questions in all. The questions were sub-divided into; environmental hygiene; general cleanliness of environment/housekeep; personal hygiene; other measures which include eating in the workplace, smoking at workplace. Each desirable response was scored 1 point while the undesirable response was scored zero. The total obtainable score for the practice questions was 14 . The score of 0 to 7 was graded as poor practice of occupational safety measures while score 8 to 14 was graded as good practice of occupational safety measures.

\section{Data Analysis}

The data collected were edited manually, entered into a micro-computer, and analyzed using the Epi-info database version 3.4.1. The pre-intervention and post-intervention data were analyzed separately and comparison made for both the study and control groups. The postintervention data for study and control were also compared. Comparisons were done by cross tabulation of variables while chi-square was used to determine the statistical significance of 
observed differences in the pre-intervention and post-intervention studies. T-test was used to test the association between the mean of continuous variables. Chi-squared analyses were done to assess the association between categorical variables. P-value $<0.05$ was considered significant at the $95 \%$ confidence level.

Ethical Consideration: Ethical approval to conduct the study was obtained from the Ethical Review Committee of University of Ilorin Teaching Hospital (U.I.T.H). Individual informed consent was obtained from each participant after they had been educated about the study.

Limitations of the Study: The limitation of the study includes possible concurrent health education of the control respondents during the time of the study from other sources outside the training.

\section{RESULTS}

A total of 214 respondents were involved in the pre-intervention stage with 107 respondents each from study and control group. At post-intervention stage, 101 and 103 respondents participated from the study and the control group respectively, giving attrition rate of $6 \%$ and $4 \%$ for the study and the control.

All the respondents $(100.0 \%)$ were males for both study and the control groups. The age distribution of respondents in the study group ranged from 20 to 53 years with mean age $( \pm$ s.d. $)$ of $36.0( \pm 8.2)$ years. The control group age range from 22 to 55 years with mean age $( \pm$ s.d. $)$ of $35.3 \pm 8.4$ years. In the study group, many of the respondents $(35.5 \%)$ were in the age group of 30 39 years and $40-49$ years respectively while many $(42.1 \%)$ of the respondents from the control group were in the age group of 30-39 years. There is no statistically significant difference in the age groups of both the study and the control group $(\mathrm{P}=0.2261)$. Table 1 .

Less than half $(43.0 \%)$ of the respondents from the study group had secondary education while about a quarter $(28.0 \%)$ of the control group had secondary education. There was no significant difference in the sociodemographic characteristics of study and control group except significantly higher proportion of Christians in the study group than the control group $(\mathrm{P}<0.05)$. Table 1 .

Most of the respondents from both the study group (42.1\%) and the control (53.3\%) group have worked for 10-19 years. There was no significant difference in the occupational history of study and control group except significantly higher proportion of respondents who worked 914 hours a day in the study group than the control group $(\mathrm{P}<0.05)$. Table 2 .

One fifth $14(20.0 \%)$ of the respondents with 1-19 year of working experience among the study group had good knowledge of hazards of lead acid battery while $3(8.1 \%)$ of the respondents with 20-39 years' experience among study group had good knowledge of hazards of lead acid battery. However, the difference was not statistically significant, $\mathrm{P}=0.1860$. Table 3 .

Less than one-fifth $(15.9 \%)$ of the study group had good knowledge of hazards relating to battery which increased significantly to more than three-quarters (76.2\%) post-intervention $(\mathrm{P}=0.0000)$. The proportion of the control group with good knowledge of hazards increased from less than one-fifth (17.8\%) to nearly a quarter (22.3\%) post-intervention. However, the difference was not significant $(\mathrm{P}=0.4075)$. There was significant improvement in the proportion of respondents with good knowledge of safety measures only among the study group from nearly half $(43.9 \%)$ to nearly three-quarter $(73.3 \%)(\mathrm{P}=0.0001)$. Table 4 .

The majority $(85.0 \%)$ of the study group and $(86.0 \%)$ of the control group had positive attitude towards safety measures preintervention. The proportion with positive attitude increased marginally $(85.1 \%)$ among the study and (87.4\%) among the control. Neither change in attitude among the study group nor among the control was significant $(\mathrm{P}>0.05)$. Table 5

The proportion of the respondents with good practice among the study group increased significantly from $6.5 \%$ pre-intervention to $17.8 \%$ post-intervention $(\mathrm{P}=0.0124)$ while in the control group the proportion with good practice increased from $15.0 \%$ pre-intervention to $18.4 \%$ post-intervention. The change in practice among the control group was not significant $(\mathrm{P}=0.4971)$. Table 6.

\section{DISCUSSION}

All the respondents $(100.0 \%)$ from both study and the control group were males. This is similar to the finding of Asogwa among battery chargers in Enugu and Sabitu among welders in Nigeria and South-South Nigeria respectively where all the respondents were of male sex.(18, 19) This might be due to physical stress and perceived hazards of the work which might be difficult for the female to cope with.

Many (35.5\%) of the study group and 
(42.1\%) of the control were in the age group of 30-39 years. There was no statistically significant difference in the age groups of both the study and the control group. This is similar to the finding in Northern Nigeria (18). The implication of this is that the battery charger who is above 40 years may have problems of poor vision and lack of strength that may be required for maintaining safety measures thereby predisposed to accidents and injuries. The absence of significant difference between the age group distribution of the study and the control demonstrated the fact that the two groups were similar and comparable with respect to age of the respondents.

The highest educational qualification of more than a half of the respondents was primary school certificate. This is in contrast to the finding of Isah in Benin-city and Sabitu in Kaduna, Nigeria, where secondary school was the highest qualification of the majority of Welders studied $(18,19)$. This may be due to the difference in the job requirement of the welders that may involve reading diagrams and measurements. Higher education is expected to empower the worker to access information on knowledge of safety measures and practices.

With low education, the workers may not have access to information beyond their master trainer and colleagues' knowledge. However, the predominantly low educational qualification of the respondents may be because of the demand of the job of battery charger.

Most of the respondents from both the study group (42.1\%) and the control $(53.3 \%)$ group have worked for 10-19 years. This is comparable to the finding of Sabitu et al. in northern Nigeria where most $(40.7 \%)$ of the artisans had worked for 10-14 years (18). The long period of work experience is expected to empower the worker to have improved knowledge of hazards and safety measures through learning by experience. However, in this study the respondents with shorter work history, 1-19 years had better knowledge of safety measures than the respondents who had worked for 20-39 years. This difference may be due to the younger battery chargers being more likely to access more recent information on safety practices than the older workers.

Majority of the respondents with 20-39 year of working experience had good knowledge of hazards of lead acid battery which is similar to $65.1 \%$ of small scale industry workers in Northern Nigeria with $>20$ years of work experience who were aware of hazards of their work(18). The workers with shorter work history tend to have better knowledge of hazards of lead acid battery. This difference may be due to the younger battery chargers being more likely to access more recent information on hazards of lead acid battery than the older workers. The difference is however, not significant $(\mathrm{P}>0.05)$. Similarly, the workers with shorter work history tend to have better knowledge of safety measures. Less than one-fifth $(15.9 \%)$ of the study group had good knowledge of hazards relating to battery which increased significantly to more than three-quarters $(76.2 \%)$ post-intervention $(\mathrm{P}<0.0001)$. The proportion of the control group with good knowledge of hazards increased from less than one-fifth (17.8\%) to nearly a quarter $(22.3 \%)$ post-intervention. However, the difference was not significant $(\mathrm{P}=0.4075)$. This is similar to the finding of Wei among small scale industry workers where only $32.0 \%$ had good knowledge of hazard of their work (8).

There was significant improvement in the proportion of respondents with good knowledge of safety measures only among the study group from nearly half $(43.9 \%)$ to nearly three-quarter $(73.3 \%) \quad(\mathrm{P}=0.0000)$. Similarly, Sokas et al. reported significant improvement in the knowledge of hazard among construction workers following training (20). Also, Lippin et al reported improvement in the safety knowledge of the small scale industry workers following training intervention (21).

There was no statistically significant improvement in the median score of attitude among the study group post-intervention $(\mathrm{P}=0.0890)$. This is a contrast to the findings of Sokas et al. among construction workers where there was sustained significant improvement in the knowledge and attitude scores three months post training intervention (20). This was probably due to the reinforcement effect of two separate sessions of training in Soka's study while this study exposed the respondents to only a session of training.

More than three-quarter $(77.6 \%)$ of the study group and about half of the control group $(52.3 \%)$ had positive attitude to use of glove at work pre-intervention. Similarly, $90.0 \%$ of Cambodian battery chargers had favourable attitude to personal protective equipment (16). There was slight improvement in the study $(84.1 \%)$ and control $(56.3 \%)$ post-intervention. The absence of significant improvement in the respondents' attitude to safety measures is a limitation of this study and future studies should evaluate effects of more than one session of training over longer study duration. Also, the 
proportions of the respondents with the positive attitude to safety measure were already high preintervention, thereby making the observed increment insignificant. To achieve a significant improvement in attitude, an individual is expected to have been exposed to repeated training and reinforcement of knowledge and personal experience over a reasonable period of time.

The safety practice of about one-tenth of the respondents was rated good. This increased significantly to almost one-fifth $(17.8 \%)$ postintervention $(\mathrm{P}=0.0124)$ only in the study group. Similarly, Lippin et al. reported a significant improvement in the workplace practice of safety measures among workers (21). Similarly, the mean score of practice was low among the study group and the control group pre-intervention and post-intervention. However, there was significant improvement in the mean score of practice only among the study group from (4.0) pre-intervention to (4.7) post-intervention $(\mathrm{P}=0.0073)$.

None of the workshops belonging to either group pre-intervention and postintervention had a single face mask; respirator; apron; safety booth; or goggle The implication of this finding is that the actual number of workers that actually use personal protective devices may likely be well below the self-reported use in the quantitative report of this study.

None of the workshop belonging to either group pre-intervention or post-intervention had any warning sign in the work area. The implication of lack of warning signs is that unsuspected costumers and the community members including pregnant women and children may have repeated exposure to the hazards at the workshops, which might be prevented if they were informed of the hazard through warning sign.

There was significant improvement in the knowledge of hazards of lead acid battery, knowledge of preventive measures against hazards of lead acid battery and the self-reported use of personal protective devices by the respondents only among the study group postintervention. The improvement in the attitude to use of personal protective devices was not significant.

\section{CONCLUSION}

There was significant improvement in the knowledge of hazards relating to battery work and practice of safety measures only in the study group. However, majority of the respondents had positive attitude towards pre-intervention. There was no significant improvement in attitude in either group post intervention.

Recommendations: The lead Acid Battery Workers should be educated on the need to always use protective devices at work. This can be achieved through their association working in conjunction with the health institutions to organize seminars and trainings on hazards prevention and safety measures.

Conflict of interest: None to disclose.

\section{REFERENCES}

1. Finish line batteries. Battery Overview: Lead Acid Batteries. 2019 [14/06/2019]; Available from: http://batteriesbyfisher.com/batteryoverview.

2. Singh R, Gautam N, Mishra A, Gupta R. Heavy metals and living systems: An overview. Indian J Pharmacol. 2011;43(3):246-53.

3. Ahmad SA, Khan MH, Khandker S, Sarwar AFM, Yasmin N, Faruquee MH, et al. Blood Lead Levels and Health Problems of Lead Acid Battery Workers in Bangladesh. The Scientific World Journal. 2014;2014:7.

4. Agency for Toxic Substances and Disease Registry. Lead Toxicity; Where Is Lead Found. 2017 [14/06/2019]; Available from: https://www.atsdr.cdc.gov/csem/csem.asp?csem $=34 \& \mathrm{po}=5$.

5. International Programme on Chemical Safety. Environmental Health Criteria 165: Inorganic Lead. Geneva: International Program on Chemical Safety; 2019 [14/06/2019]; Available $\begin{array}{lllll}\mathrm{f} & \mathrm{r} & \mathrm{o} & \mathrm{m}\end{array}$ http://www.inchem.org/documents/ehc/ehc/ehc1 65.htm.

6. Kimani NG. Blood Lead Levels in Kenya: A Case Study for Children and Adolescents in Selected Areas of Nairobi and Olkalou, Nyandarua District. Nairobi: The United Nations Environment Programme(UNEP); 2005. p. 1-26.

7. Taha AZ. Knowledge and practice of preventive measures in small industries in Al-Khobar. Saudi Med J. 2000;21(8):740-5.

8. Wei L, Shi-Da W. Occupational health management and service for small-scale industries in Shanghai. Toxicology. 2004;198(13):55-61.

9. Mastrangelo G, Perticaroli S, Camipo G, Priolo G, Leva A, de Merich D, et al. Working and health conditions and preventive measures in a random sample of 5000 workers in the Veneto Region examined by telephone interview. Med Lav. 2008;99 Suppl 1:9-30.

10. United Nations Conference on Trade and Development Small battery recycling plants, environmental and occupational health 
assessment. Philippine Project Field Study Report [Internet]. 1998 12/03/2009:[15-21 pp.]. A v a i l a b l e f r o m : http://www.unctad.org/trade_env/docs/Infofv.pdf.

11. Karita K, Nakao M, Ohwaki K, Yamanouchi Y, Nishikitani M, Nomura K, et al. Blood lead and erythrocyte protoporphyrin levels in association with smoking and personal hygienic behaviour among lead exposed workers. Occup Environ Med. 2005;62(5):300-3.

12. Lormphongs S, Morioka I, Miyai N, Yamamoto $\mathrm{H}$, Chaikittiporn C, Thiramanus $\mathrm{T}$, et al. Occupational health education and collaboration for reducing the risk of lead poisoning of workers in a battery manufacturing plant in Thailand. Ind Health. 2004;42(4):440-5.

13. Safety Health Assessment and Research for Prevention (SHARP) Program. Occupational Lead Exposure: A Health Care Provider Alert Safety, Health Assessment and Research for Prevention (SHARP) Program; 2001.p. 1-4.

14. World Heath Organization. Children's Health and the Environment. WHO Training Package for the Health Sector. Geneva: WHO; 2008. p. 1-59.

15. Varkevisser CM, Pathmanathan I, Brownlee A. Designing and Conducting Health Systems Research Projects Proposal Development and Fieldwork. Amsterdam: Jointly published by KIT Publishers and the International Development
Research Centre (IDRC), in association with the Africa Regional Office (AFRO) of the World Health Organization; 2003. p. 184-93.

16. Penh P. Status of Used Lead Acid Battery Management in Kingdom of Cambodia. UNEP Technical Report. 2004:16-20.

17. World Heath Organization. Air Quality Guidelines. Chapter 67 Lead 2nd ed: WHO Regional Office for Europe, Copenhagen, Denmark.; 2001.p. 1-17.

18. Sabitu K, Iliyasu Z, Dauda MM. Awareness of occupational hazards and utilization of safety measures among welders in Kaduna metropolis, Northern Nigeria. Ann Afr Med. 2009;8(1):4651.

19. Isah EC, Okojie OH. Occupational Health Problems of Welders in Benin City, Nigeria. Journal of Medicine and Biomedical Research. 2006;5(1):64-9.

20. Sokas RK, Emile J, Nickels L, Gao W, Gittleman JL. An intervention effectiveness study of hazard awareness training in the construction building trades. Public Health Rep. 2009;124 Suppl 1:1608.

Lippin TM, Eckman A, Calkin KR, McQuiston TH. Empowerment-based health and safety training: evidence of workplace change from four industrial sectors. Am J Ind Med. 2000;38(6):697-706. 
Table 1: Socio-demographic characteristics of the respondents

\begin{tabular}{|c|c|c|c|c|}
\hline Variables & & $\begin{array}{l}\begin{array}{l}\text { Study }(\%) \\
(n=107)\end{array} \\
\end{array}$ & $\begin{array}{l}\begin{array}{l}\text { Control }(\%) \\
(n=107)\end{array} \\
\end{array}$ & \\
\hline \multirow{4}{*}{$\begin{array}{l}\text { Age } \\
\text { distribution }\end{array}$} & 20-29 Years & $25(23.4)$ & $27(25.2)$ & \multirow{4}{*}{$\begin{array}{l}\mathrm{P}=0.2261 \\
\mathrm{X}^{2}=4.35\end{array}$} \\
\hline & 30-39 Years & $38(35.5)$ & $45(42.1)$ & \\
\hline & 40-49 Years & $38(35.5)$ & $25(23.4)$ & \\
\hline & 50-59 Years & $6(5.6)$ & $10(9.3)$ & \\
\hline \multirow{2}{*}{$\begin{array}{l}\text { Sex } \\
\text { distribution }\end{array}$} & Male & $107(100.0)$ & $107(100.0)$ & \\
\hline & Female & $0(0.0)$ & $0(0.0)$ & \\
\hline \multirow{2}{*}{$\begin{array}{l}\text { Marital status } \\
\text { Distribution }\end{array}$} & Married & $93(86.9)$ & $83(77.6)$ & \multirow{2}{*}{$\begin{array}{l}\mathrm{P}=0.0737 \\
\mathrm{X}^{2}=3.1998\end{array}$} \\
\hline & Single & $14(13.1)$ & $24(22.4)$ & \\
\hline \multirow{4}{*}{$\begin{array}{l}\text { Highest } \\
\text { educational } \\
\text { qualification }\end{array}$} & No Formal & $2(1.9)$ & $6(5.6)$ & $\mathrm{P}=0.0757$ \\
\hline & Arabic & $4(3.7)$ & $3(2.8)$ & \multirow{3}{*}{$\mathrm{X}^{2}=6.89$} \\
\hline & Primary & $55(51.4)$ & $68(63.6)$ & \\
\hline & Secondary & $46(43.0)$ & $30(28.0)$ & \\
\hline \multirow{2}{*}{$\begin{array}{l}\text { Religion } \\
\text { distribution }\end{array}$} & Christianity & $30(28.0)$ & $6(5.6)$ & \multirow{2}{*}{$\begin{array}{l}\mathrm{P}=0.0000 \\
\mathrm{X}^{2}=19.24\end{array}$} \\
\hline & Islam & $77(72.0)$ & $101(94.4)$ & \\
\hline \multirow[t]{2}{*}{ Ethnic group } & Hausa & $3(2.8)$ & $0(0.0)$ & \multirow{2}{*}{$\begin{array}{l}\text { Fisher exact } \\
\mathrm{P}=0.1232\end{array}$} \\
\hline & Yoruba & $104(97.2)$ & $107(100.0)$ & \\
\hline
\end{tabular}

Table 2: Occupational history of respondents

\begin{tabular}{|c|c|c|c|}
\hline Variables & $\begin{array}{l}\text { Study } \\
(\%) \\
(n=107)\end{array}$ & $\begin{array}{l}\text { Control } \\
(\%) \\
(n=107)\end{array}$ & \\
\hline \multicolumn{4}{|l|}{ Years of work Experience } \\
\hline $1-9$ & $25(23.4)$ & $24(22.4)$ & \multirow{4}{*}{$\begin{array}{l}P=0.0668 \\
X^{2}=7.1669\end{array}$} \\
\hline $10-19$ & $45(42.1)$ & $57(53.3)$ & \\
\hline $20-29$ & $32(29.9)$ & $17(15.9)$ & \\
\hline $30-39$ & $5(4.7)$ & $9(8.4)$ & \\
\hline \multicolumn{4}{|c|}{ Number of working Days per week } \\
\hline $4-5$ & $8(7.5)$ & $17(15.9)$ & $\mathrm{P}=0.0554$ \\
\hline $6-7$ & $99(92.5)$ & $90(84.1)$ & $X^{2}=3.6686$ \\
\hline \multicolumn{4}{|l|}{ Number of hours Work per day } \\
\hline $2-8$ & $23(21.5)$ & $36(33.6)$ & $\mathrm{P}=0.0467$ \\
\hline $9-14$ & $84(78.5)$ & $71(66.4)$ & $X^{2}=3.9547$ \\
\hline \multicolumn{4}{|c|}{ Average number of batteries handled Per week } \\
\hline $1-5$ & $51(47.7)$ & $68(63.6)$ & $\mathrm{P}=0.0521$ \\
\hline $6-10$ & $50(46.7)$ & $33(30.8)$ & $X^{2}=5.9105$ \\
\hline $11-15$ & $6(5.6)$ & $6(5.6)$ & \\
\hline
\end{tabular}

Table 3: Respondents' pre-intervention knowledge of hazards by duration of work experience

\begin{tabular}{|c|c|c|c|c|}
\hline Years of & \multicolumn{2}{|c|}{ Study $(n=107)$} & \multicolumn{2}{|c|}{ Control $(n=107)$} \\
\hline Working & \multicolumn{2}{|c|}{ Knowledge score } & \multicolumn{2}{|c|}{ Knowledge score } \\
\hline Experience & $\begin{array}{l}\text { Poor } \\
(0-8)\end{array}$ & $\begin{array}{l}\text { Good } \\
(9-15)\end{array}$ & $\begin{array}{l}\text { Poor } \\
(0-8)\end{array}$ & $\begin{array}{l}\text { Good } \\
(9-15)\end{array}$ \\
\hline $1-19$ & $56(80.0)$ & $14(20.0)$ & $64(79.0)$ & $17(21.0)$ \\
\hline 20-39 & $34(91.9)$ & $3(8.1)$ & $24(92.3)$ & $2(7.7)$ \\
\hline \multirow[t]{2}{*}{ Total } & $90(84.1)$ & $17(15.9)$ & $88(82.2)$ & $19(17.8)$ \\
\hline & \multicolumn{2}{|c|}{ Yates' $\mathrm{x}^{2}=1.75 ; \mathrm{P}=0.1860$} & \multicolumn{2}{|c|}{ Yates' $\mathrm{x}^{2}=1.56 ; \mathrm{P}=0.2118$} \\
\hline
\end{tabular}


Table 4: Effect of training on respondents' knowledge score

\begin{tabular}{|c|c|c|c|c|}
\hline \multirow{2}{*}{$\begin{array}{l}\text { Knowledge } \\
\text { score }\end{array}$} & \multicolumn{2}{|l|}{ Study (\%) } & \multicolumn{2}{|l|}{ Control (\%) } \\
\hline & $\begin{array}{l}\text { Pre- } \\
\text { intervention } \\
(n=107)\end{array}$ & $\begin{array}{l}\text { Post- } \\
\text { intervention } \\
(\mathrm{n}=101)\end{array}$ & $\begin{array}{l}\text { Pre- } \\
\text { intervention } \\
(\mathrm{n}=107)\end{array}$ & $\begin{array}{l}\text { Post- } \\
\text { intervention } \\
(n=103)\end{array}$ \\
\hline \multicolumn{5}{|l|}{ Hazards } \\
\hline Good (9-15) & $17(15.9)$ & $77(76.2)$ & $19(17.8)$ & $23(22.3)$ \\
\hline Poor $(0-8)$ & $\begin{array}{l}90(84.1) \\
X^{2}=76.3989 ; P=0.0000\end{array}$ & $24(23.8)$ & $\begin{array}{l}88 \text { (82.2) } \\
\mathrm{X}^{2}=0.6860 ; \quad \mathrm{P}=0.4075\end{array}$ & $80(77.7)$ \\
\hline $\begin{array}{l}\text { Mean (s.d.) } \\
\text { T-statistics }\end{array}$ & $\begin{array}{l}6.5( \pm 2.0) \\
\mathrm{t}=12.4 ; \mathrm{P}=0.0001\end{array}$ & $10.5( \pm 2.6)$ & $\begin{array}{l}6.2( \pm 2.7) \\
t=1.2 ; P=0.2342\end{array}$ & $6.7( \pm 2.6)$ \\
\hline \multicolumn{5}{|c|}{ Safety measures } \\
\hline Good (9-15) & $47(43.9)$ & $74(73.3)$ & $30(28.0)$ & $39(37.9)$ \\
\hline Poor $(0-8)$ & $\begin{array}{l}60(56.1) \\
\left(x^{2}=18.3843 \mathrm{P}=0.0001\right)\end{array}$ & $27(26.7)$ & $\begin{array}{l}77(72.0) \\
\left(x^{2}=2.2971 \quad \mathrm{P}=0.1296\right)\end{array}$ & $64(62.1)$ \\
\hline $\begin{array}{l}\text { Mean (s.d.) } \\
\text { T-statistics }\end{array}$ & $\begin{array}{l}7.9( \pm 2.8) \\
t=7.7653 ; P=0.0000\end{array}$ & $11.2( \pm 3.3)$ & $\begin{array}{l}7.0( \pm 3.0) \\
\mathrm{t}=1.8195 ; \mathrm{P}=0.0703\end{array}$ & $7.7( \pm 3.0)$ \\
\hline
\end{tabular}

Table 5: Effect of training on respondents' attitude score

\begin{tabular}{|c|c|c|c|c|}
\hline \multirow[b]{2}{*}{ Attitude } & \multicolumn{2}{|l|}{ Study (\%) } & \multicolumn{2}{|l|}{ Control (\%) } \\
\hline & $\begin{array}{l}\text { Pre- } \\
\text { intervention } \\
(\mathbf{n}=107)\end{array}$ & $\begin{array}{l}\text { Post- } \\
\text { intervention } \\
(\mathbf{n}=101)\end{array}$ & $\begin{array}{l}\text { Pre- } \\
\text { intervention } \\
(\mathrm{n}=107)\end{array}$ & $\begin{array}{l}\text { Post- } \\
\text { intervention } \\
(n=103)\end{array}$ \\
\hline $\begin{array}{l}\text { Negative attitude } \\
(2-5)\end{array}$ & $16(15.0)$ & 15 (14.9) & $15(14.0)$ & $13(12.6)$ \\
\hline Positive attitude & $91(85.0)$ & $86(85.1)$ & $92(86.0)$ & $90(87.4)$ \\
\hline $\begin{array}{l}\text { Median score (s.d.) } \\
\text { t-statistics }\end{array}$ & $\begin{array}{l}\mathrm{X}^{2}=0.0004 ; \mathrm{P}=0.9836 \\
9.0( \pm 2.7) \\
\mathrm{t}=1.7088 ; \mathrm{P}=0.0890\end{array}$ & $10.0( \pm 2.7)$ & $\begin{array}{l}\mathrm{X}^{2}=0.0887 ; \mathrm{P}=0.7659 \\
8.0( \pm 2.0) \\
\mathrm{t}=0.0208 ; \mathrm{P}=0.9834\end{array}$ & $8.0( \pm 1.9)$ \\
\hline
\end{tabular}

Table 6: Effect of training on respondents' practice of safety measures category

\begin{tabular}{|c|c|c|c|c|}
\hline \multirow[b]{2}{*}{ Safety practice } & \multicolumn{2}{|l|}{ Study (\%) } & \multicolumn{2}{|l|}{ Control (\%) } \\
\hline & $\begin{array}{l}\text { Pre- } \\
\text { intervention } \\
(n=107)\end{array}$ & $\begin{array}{l}\text { Post- } \\
\text { intervention } \\
(n=101)\end{array}$ & $\begin{array}{l}\text { Pre- } \\
\text { intervention } \\
(\mathrm{n}=107)\end{array}$ & $\begin{array}{l}\text { Post- } \\
\text { intervention } \\
(n=103)\end{array}$ \\
\hline $\begin{array}{l}\text { Good practice } \\
(0-8)\end{array}$ & $7(6.5)$ & $18(17.8)$ & $16(15.0)$ & $19(18.4)$ \\
\hline \multirow{2}{*}{$\begin{array}{l}\text { Poor practice } \\
(9-15)\end{array}$} & $100(93.5)$ & $83(82.2)$ & $91(85.0)$ & $84(81.6)$ \\
\hline & $\mathrm{X}^{2}=6.2514 ; \mathrm{P}=0.0124$ & & $\mathrm{X}^{2}=0.4611 ; \mathrm{P}=0.4971$ & \\
\hline \multirow[t]{2}{*}{$\begin{array}{l}\text { Mean score (s.d.) } \\
\text { t-statistics }\end{array}$} & $\begin{array}{l}4.0( \pm 2.1) \\
\mathrm{t}=2.7105 ; \mathrm{P}=0.0073\end{array}$ & $4.7( \pm 2.4)$ & $4.9( \pm 2.2)$ & $5.2( \pm 2.2)$ \\
\hline & & & $\mathrm{t}=0.9093 ; \mathrm{P}=0.3643$ & \\
\hline
\end{tabular}

